\title{
Multi-methodological approaches to investigate lower urinary tract function in health and disease
}

Citation for published version (APA):

Walter, M. (2018). Multi-methodological approaches to investigate lower urinary tract function in health and disease. [Doctoral Thesis, Maastricht University]. Datawyse / Universitaire Pers Maastricht. https://doi.org/10.26481/dis.20180305mw

Document status and date:

Published: 01/01/2018

DOI:

10.26481/dis.20180305mw

Document Version:

Publisher's PDF, also known as Version of record

\section{Please check the document version of this publication:}

- A submitted manuscript is the version of the article upon submission and before peer-review. There can be important differences between the submitted version and the official published version of record.

People interested in the research are advised to contact the author for the final version of the publication, or visit the DOI to the publisher's website.

- The final author version and the galley proof are versions of the publication after peer review.

- The final published version features the final layout of the paper including the volume, issue and page numbers.

Link to publication

\footnotetext{
General rights rights.

- You may freely distribute the URL identifying the publication in the public portal. please follow below link for the End User Agreement:

www.umlib.nl/taverne-license

Take down policy

If you believe that this document breaches copyright please contact us at:

repository@maastrichtuniversity.nl

providing details and we will investigate your claim.
}

Copyright and moral rights for the publications made accessible in the public portal are retained by the authors and/or other copyright owners and it is a condition of accessing publications that users recognise and abide by the legal requirements associated with these

- Users may download and print one copy of any publication from the public portal for the purpose of private study or research.

- You may not further distribute the material or use it for any profit-making activity or commercial gain

If the publication is distributed under the terms of Article $25 \mathrm{fa}$ of the Dutch Copyright Act, indicated by the "Taverne" license above, 


\section{ENGLISH SUMMARY}

This doctoral dissertation addresses multi-methodological approaches to investigate the LUT in health and disease, and starts with a general overview of LUT function and dysfunction.

In the first study (Chapter 2), we examined the value of surveillance urethrocystoscopy in patients with NLUTD. It has been reported that patients with NLUTD, mostly due to SCl, are at an increased risk for bladder cancer. In the framework of the largest prospective study to date, we used the data of 129 consecutive individuals suffering from NLUTD for at least 5 years. Using surveillance urethro-cystoscopy, we found relevant histological findings, including bladder cancer, in $5 \%$ of our patients suffering from NLUTD for at least 5 years. Contrasting most of the existing literature, our results suggest that surveillance urethro-cystoscopy is necessary. As a result of this study new guidelines advocating for the inclusion of every individual with NLUTD in the surveillance urethro-cystoscopy program were introduced.

In the next study (Chapter 3), we investigated the overall incidence of AD and repeatability of cardiovascular changes in a series of 33 consecutive women with suprasacral SCI suffering from NLUTD. All patients underwent same session repeat UDI and synchronous continuous cardiovascular monitoring (SBP, $\mathrm{DBP}$, and HR). We found a high overall AD incidence during UDI. Furthermore, patients with AD presented with significant increases in SBP and DBP as well as a significant decrease in HR compared to those without AD. The repeatability of AD between the two-same session UDIs was good. However, when applying the Bland and Altman method, wide 95\% limits of agreement for differences in same session SBP, DBP and HR indicated poor repeatability. This study yielded important results into the field of neuro-urology, as there were no women-specific data available before. As a result of our study, the following recommendation has been imbedded into the European Association of Urology's Guidelines on Neuro-Urology: “Considering a high incidence of AD 
with the relevant risks involved and poor repeatability of cardiovascular changes during UDI, continuous cardiovascular monitoring and reforming repeated measurements are strongly advised."

The aim of the next study (Chapter 4), was to evaluate whether UDI, the gold standard to assess refractory LUTS, is appropriate to select healthy volunteers (i.e. without LUTS) as control subjects for comparative studies. Fortytwo healthy subjects ( 22 women, and 20 men) were included into this prospective single-centre cohort study, recording a 3-day bladder diary, completed validated questionnaires regarding LUTS, and underwent neuro-urological assessment as well as free uroflowmetry. All 3-day bladder diaries, questionnaires, neuro-urological assessments and free uroflowmetries were within normal limits. In spite of this, more than $70 \%$ of our healthy subjects had pathological UDI findings. Given these results, it seems that UDI is not applicable in healthy subjects to define normal LUT function. Therefore, we do not recommend using UDI to select healthy control subjects.

The study presented in chapter 5 outlines our intent 1) to identify brain networks of supraspinal LUT control in healthy subjects and 2) to detect abnormalities within these networks in patients with non-neurogenic LUTS. In order to facilitate these goals, we will utilize structural and fMRI techniques (in correlation with clinical measurements). This study aims to provide new insights into the supraspinal neuronal mechanisms and networks responsible for LUT control. The findings will help to verify, amend or adjust neuronal circuitry models established from findings in healthy controls, now in the context of patients with non-neurogenic LUTS. The use of newer imaging and evaluation techniques has the potential to serve as quantifiable outcome measures for therapy success and provide evidence for non-responders of LUTS treatment. Using structural and fMRI, the following study outline (Chapter 6) focuses on the investigation of the supraspinal LUT control in healthy subjects and individuals with $\mathrm{SCl}$ undergoing intradetrusor onabotulinumtoxinA injections to 
treat NLUTD. This study focuses at identifying structural and functional alterations in supraspinal networks of LUT control in SCI patients with NLUTD. Post-treatment MRI measurements in $\mathrm{SCl}$ patients will provide further insights into the intradetrusor onabotulinumtoxinA injections' effect on supraspinal LUT control.

The last study (Chapter 7 ) reports about the applicability and precision of a novel IDD for standardized filling paradigms in neuro-urology and fMRI studies of LUT function/dysfunction. The IDD is based on electrohydrostatic actuation which was previously proven feasible in a prototype setup. Our current design includes hydraulic cylinders and a motorized slider to provide force and motion. Methodological aspects have been assessed in a technical application laboratory as well as in healthy subjects and individuals with LUT dysfunction undergoing fMRI during LUT stimulation. According to our results, we were able to develop an MR-compatible and MR-synchronized IDD to routinely stimulate the LUT during fMRI in a standardized manner. The device provides LUT stimulation at high system accuracy resulting in significant supraspinal BOLD signal changes in interoceptive and LUT control areas in synchronicity to the applied stimuli. The IDD is commercially available, portable and multi-configurable. In our opinion, such a device may help to improve precision and standardization of LUT tasks in neuro-imaging studies on supraspinal LUT control, and may therefore facilitate multisite studies and comparability between different LUT investigations in the future. 